\title{
THE NEED FOR EMOTIONAL INTELLIGENT LEADERS IN BUSINESS MANAGEMENT
}

\section{Larissa Mendes Oliveira ${ }^{1}$, David Barbosa de Alencar ${ }^{2}$, Igor Felipe Oliveira Bezerra ${ }^{3}$, Laurence de Oliveira Martins ${ }^{4}$ and Jhonathan Carvalho da $\mathrm{Cruz}^{5}$}

\author{
${ }^{1,2}$ Braulo Cardoso de Mattos Higher Education Institute - FASERRA. Manaus-Amazonas, Brazil. \\ ${ }^{3}$ Nilton Lins University. Manaus-Amazonas, Brazil. \\ ${ }^{4}$ Biola University - ROSEMEAD School of Psychology. Brazil. \\ ${ }^{5}$ Galileo Institute of Technology and Education of the Amazon - ITEGAM. Manaus-Amazonas, Brazil. \\ Email: 1mo.engcivil@gmail.com, david002870@hotmail.com, igor.bezerra@uniniltonlins.edu.br, \\ laurence.martins@origem.org.br, jhonnc.cruz@gmail.com
}

Received: Aug 30th 2019

Accepted: Aug 30th 2019

Published: December 02 ${ }^{\text {th }}, 2019$

Copyright (C2016 by authors and Galileo Institute of Technology and Education of the Amazon (ITEGAM).This work is licensed under the Creative Commons Attribution International License (CC BY 4.0).

https://creativecommons.org/licen ses/by/4.0/

\section{Open Access:}

\section{INTRODUTION}

How does a good leader behave in different situations? Is it necessary to have a high Q.I to excel in good management? What are the features that stand out? What are the different types of leadership?

Good leaders hardly lose control, are confident, and know how to handle different styles of people. For leadership positions it has been proven through research that you need to have Q.E, emotional quotient, managers with high emotional intelligence have surpassed 20 times other managers, are four characteristics that stand out, among them, self-awareness, self-management, empathy and skill.

Understanding the best leadership style is one of society's main pursuits. Everything is intertwined with the ability to manage a family, a business, a country, among others. It is true that there are people who are born with more leadership skills, but none of this also prevents them from developing this ability. Most mergers require a sensitive negotiator in the direction, while many twists require more vigorous authority. But I've found that the most effective leaders are similar in one crucial respect: They all have a high degree of what has come to be known as emotional intelligence[1].

Increasingly, the marketplace needs skilled managers who can transform the team, encourage their employees, drive good change because the level of global competition between companies requires it. There are some features that stand out among great leaders, such as: Influencing Your Team;

Whenever an individual seeks to influence the behavior of others, individually or in groups, leadership occurs [2]. Do not be afraid of exposure to others; have initiative; high communication skills; be a good listener and help others; be accessible; be multitasking; always looking for news, and new technologies;

It is by stimulating innovation that the leader contributes to the development of new concepts and the use of new technologies necessary for the organization. [3].

- Know how to look for solutions to unexpected problems.;

- Know how to say no when needed

- Be authentic, have charisma, and can delegate and demand results without being hostile.

But many of these techniques are intertwined with the emotional quotient, other researchers have confirmed that 
emotional intelligence not only distinguishes exceptional leaders, but may also be associated with high performance [1].

Therefore, the purpose of this article was to analyze the behavior of leaders that provide conditions for the leaders to reach their interests, according to their perception. As specific objectives, we sought to identify the attributes of leaders and their skills for the exercise of leadership; talk about the various types of leaders; identify the most effective leader for the best development of a group within a company.

\section{BIBLIOGRAPHIC REFERENCE}

More effective leaders are similar in one crucial respect: Everyone has a high degree of what has come to be known as emotional intelligence. "Leadership is almost just emotional intelligence, especially when it comes to discerning what managers do and what leaders do, in things like taking a stand, knowing what's important to you, and pursuing your goals in partnership with others. people" [1].

A great leader is one who has this ability day after day, year after year in a wide variety of situations [4]. Leadership is the activity of influencing people by voluntarily engaging in group goals [5]. Terry). For [6], leadership is essentially the process of helping to change some key aspects to take advantage of changing economic and market conditions.

Leadership, viewed as a process, often affiliates with the direction in which the organization should go, the creation of a future, the ability to inspire employees and other key players to accept new principles and implement them, and to create strategies. , make people willing to follow, encourage and direct people so that the vision comes true despite all the obstacles [7]. It is also associated with the transfer of power to people so that they can make things happen. [8] complements that leadership is communicating the value and potential of people so clearly that they come to see it in themselves, and secondly, [5] leadership is like beauty: hard to define but easy to recognize.

According to [9], Donuts, which is a company that specializes in customer relationship and loyalty solutions, selfawareness, or emotional awareness, is the first component of emotional intelligence is deep understanding of one's emotions, weaknesses, strengths, impulses. Leaders who have this trait are more likely to realize when pride or other emotions are influencing, allowing them to be more rational and unbiased, and neither too critical nor too hopeful. People who know their limitations and strengths can hear and talk about them, interpreting as constructive criticism, people with low interpret them as a threat or sign of failure.

Self-management, people with a lot of self-control have a bad mood and impulses like everyone else, but the difference is that they can control them. Leaders with well-developed emotional intelligence don't make hasty or emotional decisions, many problems in companies arise from impulsive behaviors [10].

Empathy when a person has this trait makes it much easier to communicate assertively. A leader draws the employee's attention in a way that will not hurt the employee's feelings, facilitating understanding through constructive criticism.

Social ability involves the ability of one person to relate to another, as there is the awareness that nothing important is accomplished on its own. Teams that communicate well are teams that produce in sync.

In the development and its sub-items, we discuss the issue involved in the theme, using the theoretical references raised during the research. This is the main "body" of the article. It addresses the issue or problem that is mainly addressed through indirect citations, comprehensively and objectively, albeit with relatively small extension. It is used in literature reviews.

For [1], most leaders are classified into six types, according to the Emotional Intelligence book on forming a successful leader, but generally the first four that deliver a good result: Visionary Leader; Leader coach; Affective leader; Democratic leader; Modeling Leader; Coercive Leader.

\section{II.1 THE VISIONARY STYLE}

Through various surveys, he has come to the visionary leader, who stands out the most, as he is the most effective, so that he improves even the work climate. This style motivates people because it makes it clear how their work will fit into a promising future, so they understand that their effort is needed, as well as maximizing commitment to goals and strategies.

According to [11] through lean inceptions, which is the name given to the collaborative workshop to align a group of people on the minimum viable product to be built, the visionary leader sets standards that revolve around this future venture, after which he will have feedbacks, so that as many employees participate as everyone can see the good and bad as well as the rewards.

Visionary leader gives people freedom to design their own means; Freedom to innovate, experiment and take calculated risks;

This style works in almost every business, especially when it is under development. The approach when a leader is working with a team of experts or colleagues who are more experienced gift him. They may see the leader as pretentious or out of step. Another limitation: If a leader who tries to be visionary becomes dominant, he can destroy the egalitarian spirit of an effective team. Even with these risks, however, leaders would do well to resort to the visionary club with some frequency. It may not guarantee a hit on the first shot, but it certainly helps.

\section{II.2 THE TRAINER STYLE}

Para [1], líderes treinadores ajudam funcionários a identificarem forças e fraquezas e as vinculam às suas aspirações pessoais e profissionais. Encorajam os funcionários a criarem metas de desenvolvimento de longo prazo e os ajudam a conceber um plano para atingi-las. Fazem acordos com seus funcionários sobre seus papéis e suas responsabilidades em cumprir planos de desenvolvimento e dão instruções e feedback abundantes. O líder treinador se distingue em delegar. Dão aos funcionários tarefas desafiadoras. Em outras palavras, esses líderes estão dispostos a suportar o fracasso a curto prazo se isso estimula o aprendizado a longo prazo.

Dos seis estilos, nossa pesquisa constatou que o líder treinador é usado com menos frequência. Muitos líderes nos contaram que não têm tempo, nesta economia de alta pressão, para o trabalho lento e tedioso de ensinar as pessoas e ajudá-las a crescerem. Líderes que ignoram esse estilo estão abrindo mão de uma ferramenta poderosa. Seu impacto sobre o clima e o desempenho é notoriamente positivo.

Por outro lado, o estilo treinador faz pouco sentido quando os funcionários, por algum motivo, são resistentes ao aprendizado ou a mudar seus hábitos.

\section{II.3 THE AFFECTIVE STYLE}

If the visionary leader encourages "Come with me," the affective leader says, "People come first." This leadership style revolves around people — its proponents value individuals and 
their emotions more than tasks and goals. The affective leader strives to keep employees happy and create harmony among them. The affective leader provides ample positive feedback, providing a sense of recognition and reward for a job well done.

For [12], despite its benefits, affective style should not be used alone. Your unique focus on praise can prevent poor performance from being corrected. Employees may realize that mediocrity is tolerated. And because affective leaders rarely offer constructive advice on how to improve, employees need to figure it out on their own. When people need clear guidelines for navigating complex changes, affective style drifts them. In fact, if you trust him too much, this style can lead a group to failure. Perhaps this is why many affective leaders use this style in conjunction with the visionary style. Visionary leaders set a vision, set standards, and inform people how their work is promoting the group's goals. Alternate that with the affective leader's compassionate, protective approach, and you'll have a powerful combination.

\section{II.4 THE DEMOCRATIC STYLE}

By letting workers intervene in decisions that affect their determinations, the democratic leader increases flexibility and accountability. And by worrying about listening to the team's concerns, the democratic leader learns what to do to keep morale high, according to [1]. Finally, because they have an influence in setting their goals and standards for measuring success, people in a democratic system tend to be very realistic about what can and cannot be achieved.

However, the democratic style has its drawbacks, so its impact on the organizational climate becomes not as good as some of the other styles. One of its most exasperating results may be incessant meetings in which ideas are brooded, consensus remains vague, and the only visible result is the appointment of new meetings. And even if a leader has a strong vision, democratic style works well to generate new ideas to carry out that vision. Of course, the democratic style makes much less sense when employees are not competent or knowledgeable enough to offer sensible advice.

\section{II.5 THE MODELING STYLE}

The modeling style has its place in the leader's repertoire, but must be used with control. The leader preaches extremely high performance standards and personally exemplifies them to [1]. He is obsessed with doing things better and faster, and asks the same about everyone around him. Quickly points out poor performance and asks more of employees. If they do not live up to expectations, they are replaced by others because everyone is considered replaceable. The approach works well when all employees are motivated, highly competent, and need limited guidance or coordination - for example, it can work with leaders of highly qualified and motivated professionals, such as R\&D groups or advocacy teams. And, given a talented team to lead, pacemaking does just that: ensures work gets done on time or even sooner. But like any leadership style, the modeler should never be used alone.

\section{II.6 THE COERCIVE STYLE}

According to [13], understanding is accessible because, of all leadership styles, coercive is the least convenient in most situations. Consider what style does for an organization's climate. Flexibility is the hardest hit. Extreme decision-making by the topdown leader kills new ideas at the root. Similarly, people's sense of duty or obligation evaporates: unable to act on their own, the spirit of participation disappears and they feel little responsible for their performance.

Coercive leadership also has a detrimental effect on the reward system. Most high performing employees are encouraged for more than money - they seek job satisfaction well done. Coercive style destroys this pride. And finally, style undermines one of the leader's key tools: motivating people by showing how their work fits into the larger shared mission.

\section{MATERIAL AND METHODS}

The method used was the case study, because there are several characteristics within companies that classify the styles of leaders, where the objective is to get a comprehensive view of the problem under study.

With this work will be done a survey of the data, and will show what is the best style to use in a management.

\section{RESULTS AND DISCUSSION}

The data were analyzed by tabulating research collected from various authors regarding the different company leaders of the century XXI.

The research results are described below and also represented by graphs, aiming to provide clarity in the visualization and interpretation of the answers.

According to studies by teachers Jack Zenger and Joseph Folkman interviewing 300,000 CEOs and executives, successful leaders need to master a variety of skills, the most cited being.
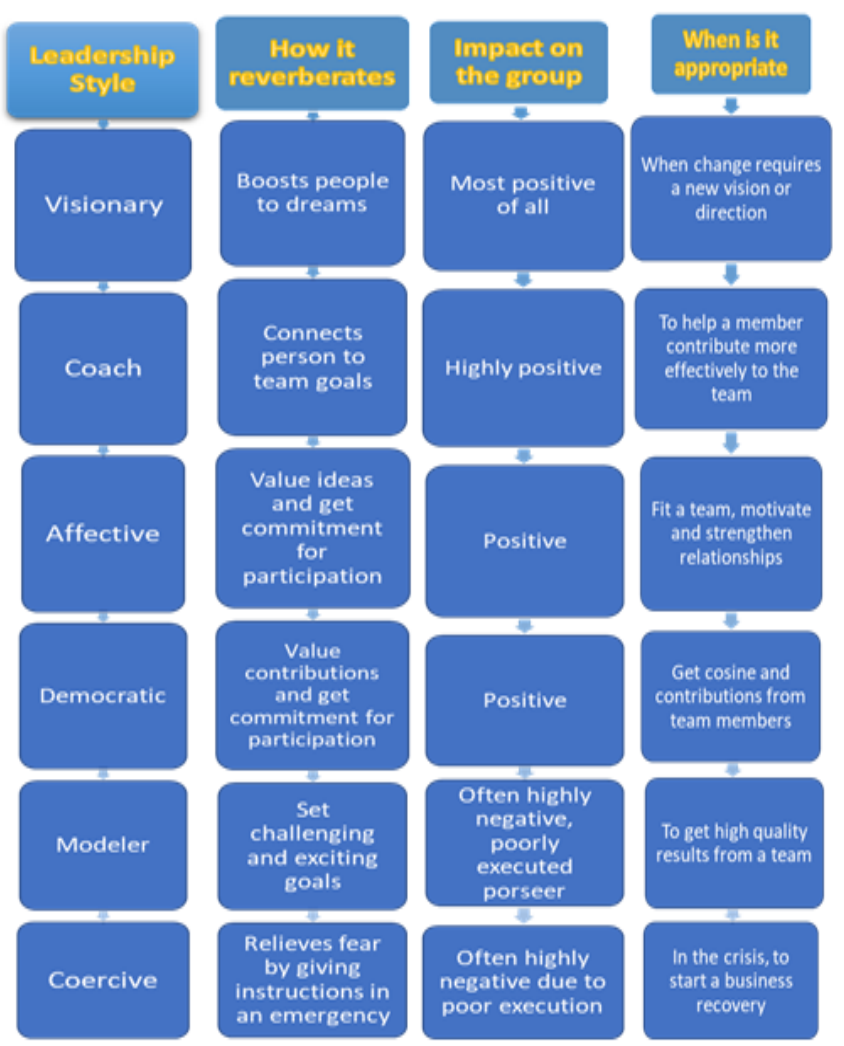

Figure 1: Leader Styles and Their Roles.

Source: Authors, (2019).

As we can see, even the fourth style is the most positive leader, and the visionary style and the coach deserve special mention because of their positive repercussions. Since the most outstanding skills among them are: 


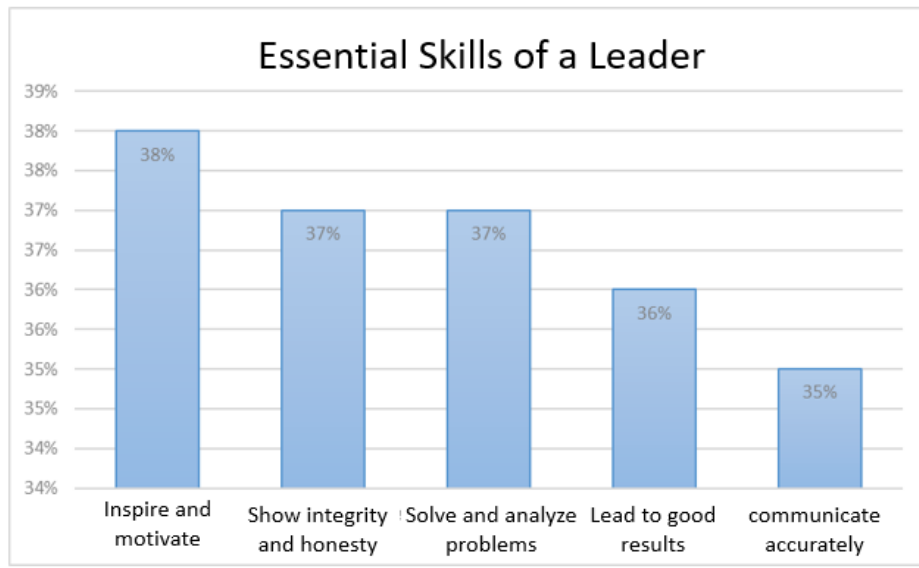

Figure 2: Distribution of Essential Skills of Leaders. Source: Authors, (2019).

A Hay / Mcber Consulting survey, based on a random sample of 3781 executives selected from a database of more than 20,000 executives worldwide, eliminates much of the mystery of effective leadership. The research focused on the six styles previously mentioned, but as for the style analyzed separately, which brings more results for companies, are:

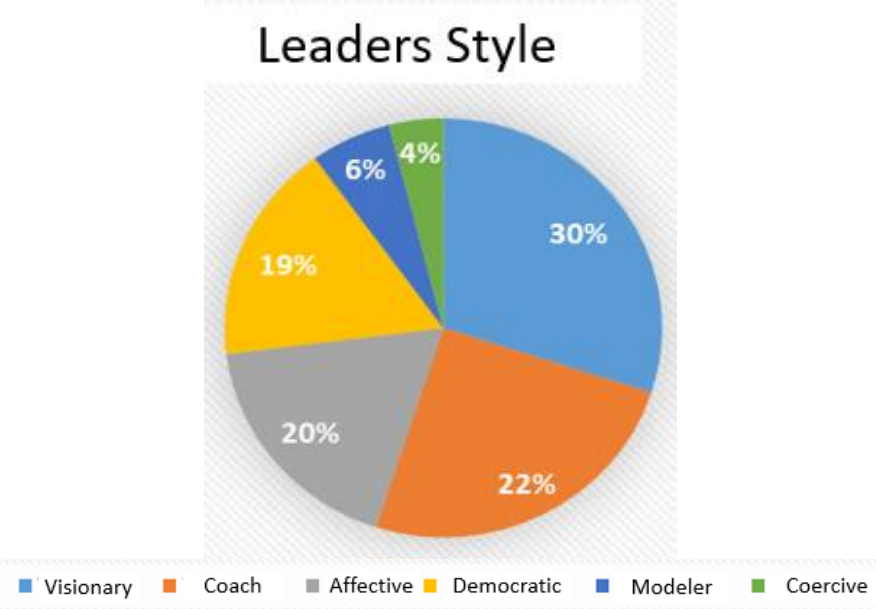

Figure 3: Most Effective Leader Styles.

Source: Authors, (2019).

Then we can compare Figure 1 and Figure 2, and confirm that the visionary and the coach bring more positive results for companies.

\section{FINAL CONSIDERATIONS}

After studies, including this one, it can be seen through the descriptions and graphs that the most positive styles are the first two (visionary and coach), but in FIgure 3, it can be seen that people's inspiration and motivation, resolution, Problem analysis and good driving are repercussions, or attitudes, of visionary, coaching, affective, and democratic leaders. In other words, leaders who master four or more styles achieve the best climate and business performance.

The most effective leaders flexibly switch leadership styles as needed. To do this, leaders must first understand which emotional intelligence competencies underpin leadership styles they lack. They can then work assiduously to increase the degree of each. For example, an affective leader is strong in three emotional intelligence skills: empathy, relationship building, and communication. Empathy allows the affective leader to react to employees in a way that is highly consistent with that person's emotions, which ensures rapport. This leader also has a natural ease in developing affective bonds, mastering the art of interpersonal communication. As another example, a visionary leader who wants to add democratic style to his repertoire will need to train communication skills.

\section{REFERENCES}

[1] Goleman, Daniel, Liderança [recurso eletrônico]: a inteligência emocional na formação do líder de sucesso; tradução Ivo Korytowski. -1.ed. - Rio de Janeiro: Objetiva, 2015.

[2] Hersey, Paul; Blanchard, Kenneth. Psicologia para administradores: a teoria e as técnicas da liderança situacional. São Paulo: EPU, 1986.

[3] Kanter, Rosabeth M. The enduring skills of change leaders. Ivey Business Journal. Londres, v. 64, May/Jun. 2000.

[4] Jenkins, Henry. Cultura da convergência. Aleph, 2015.

[5] Bennis, Warren. A formação do líder. São Paulo: Atlas, 1996.

[6] Kotter, John P. “Os Líderes Necessários”: In: Julio, Carlos Alberto e Silibi Neto, José (Org.) Liderança e Gestão de Pessoas: autores e conceitos imprescindíveis. São Paulo: Publifolha. 2002.

[7] Perrenoud, Philippe. Dez novas competências para ensinar. Artmed editora, 2015.

[8] Covey, Stephen R. Os sete hábitos das pessoas altamente eficazes. São Paulo : Best Seller, 2003 14ª edição.

[9] Ikeda, Jorge, et al. Benchmarking de franquias da rede Dunkin'donuts, através do data envelopment analysis. Anais, 1998.

[10] Da Silva Barreto, Leilianne Michelle Trindade, et al. Cultura organizacional e liderança: uma relação possível?. Revista de Administração, 2013, 48.1: 34-52.

[11] Carol, Paulo, Palestra lean inception. Congregarh 2019.

[12] De Melo, José Marques. Comunicação, região e desenvolvimento. UNIDERP, 2004.

[13] Marques, José R. O poder do elogio. Jrmcoaching. 2019. 